\title{
THE CONJUGATED, NON-PROTEIN, AMINO ACIDS OF PLASMA. IV. A DIFFERENCE IN THE UTILIZATION OF THE PEPTIDES OF HYDROLYSATES OF FIBRIN AND CASEIN
}

\author{
By HALVOR N. CHRISTENSEN, ELEANOR L. LYNCH, DAVID G. DECKER, AND \\ JOHN H. POWERS
}

(From The Mary Imogene Bassett Hospital, Cooperstoun, N. Y.)

(Received for publication January 9, 1947)

Peptides are utilized much less readily than free amino acids upon the intravenous infusion of a partial enzymatic hydrolysate of casein (Amigen), as indicated by the greater accumulation and longer persistence of peptides in plasma, and their loss to the extent of 36 to 53 per cent into the urine (1). However, a partial acid hydrolysate of fibrin twice as rich in peptides as Amigen (containing about $2 / 3$ of its amino acids in a conjugated state) has been found to have a high biological value upon intravenous administration to dogs, as compared with fibrin given orally (2). These observations suggest a possibility of considerable interest to the subject of peptide metabolism, namely, that the peptides derived from fibrin may be more efficiently utilized than those of the casein hydrolysate. This we have found to be the case.

Five per cent solutions of the fibrin hydrolysate in 5 per cent glucose were infused intravenously into convalescent male patients and into a normal subject, in 3 different quantities-1,000 ml., $878 \mathrm{ml}$, and $485 \mathrm{ml}$.,- the latter 2 quantities supplying according to our analysis the same quantity of total $\alpha$-amino nitrogen and bound $\alpha$-amino nitrogen respectively, as a liter of 5 per cent Amigen. (The fibrin hydrolysate was not only much richer in peptides because of the limited hydrolysis, but also somewhat richer in total amino acids.).

With the 2 larger portions, containing 2 to 2.3 times the quantity of peptides supplied by a liter of Amigen, dialyzable amino acid conjugates (peptides ${ }^{1}$ ) reached concentrations in plasma somewhat higher than for Amigen at similar infusion rates (Table I). However, when the quantities of peptides infused were alike, the plasma levels were lower with the fibrin hydrolysate. The highest

1 The term peptides will be used here for the dialyzable amino acid conjugates, although other nonprotein conjugates besides peptides may be included. level of peptide $\alpha$-amino nitrogen yet observed, 6.3 mgm. per cent, was not associated with discomfort. The infusion of either hydrolysate brought the free $\alpha$-amino acid nitrogen of plasma to levels lower than were observed before the infusions. The curves picturing the removal of the conjugates from plasma show the same aspects with the 2 hydrolysates (Figure 1). Without regard to the rate or quantity of the infusion, the loss of peptides into the urine was less for the fibrin hydrolysate, 26 to 28 per cent of the peptides infused (Table II). For infusion times of 1.5 to 4 hours, losses of 40 to 53 per cent were characteristic for the peptides of 1 liter of 5 per cent Amigen. In the 2 cases where the conditions were most similar (experiment 52, reported previously [1], and experiment 14 ), the same quantity of peptides being infused into the same normal subject in very nearly the same time interval, the loss of peptides was 27 per cent for the fibrin hydrolysate and 53 per cent for the Amigen. The losses of free $\alpha$ amino acids were larger during infusion of the fibrin hydrolysate than when Amigen was injected. Undoubtedly a part of the free amino acids in the urine originated from infused peptides of the hydrolysates. The over-all urinary losses of $\alpha$ amino acids (free + peptide) of both preparations were in the region of 20 per cent.

The additional conjugates of the experimental urines appeared to be peptides. The optical density (at $515 \mathrm{~m} \mu$ ) given with the biuret reaction by the dialysate of experimental urine number 24 bore a relation to that given by the fibrin hydrolysate solution similar to the relation found between the conjugated amino nitrogen concentrations of the 2 solutions. Of the conjugated amino acid nitrogen of normal human urine, ordinarily about half is extracted, after acidification, by ethyl acetate and is probably due largely to acyl amino acids, 
TABLE I

Plasma amino acid changes produced by the infusion of the fibrin hydrolysate

Five per cent solution in 5 per cent glucose, containing per liter 7.2 grams $N, 1.98$ grams free $\alpha$-amino $N, 3.44$ grams bound $\alpha$-amino N. Experiment 6, patient with duodenal ulcer; experiment 10, patient 3 days after hernioplasty; experiment 24, patient convalescent from diverticulitis, on low residue diet; experiment 14, normal person.

\begin{tabular}{|c|c|c|c|c|c|c|c|c|c|c|}
\hline $\begin{array}{c}\text { Experi- } \\
\text { ment } \\
\text { No. }\end{array}$ & $\underset{\text { infused }}{\text { Vol. }}$ & $\begin{array}{l}\text { Time for } \\
\text { infusion }\end{array}$ & $\alpha$-amino $N$ & $\begin{array}{c}\text { Before } \\
\text { infusion }\end{array}$ & $\begin{array}{c}\text { Mid- } \\
\text { infusion }\end{array}$ & $\begin{array}{c}\text { End of } \\
\text { infusion }\end{array}$ & $\begin{array}{l}1 \mathrm{hr} . \\
\text { after }\end{array}$ & $\begin{array}{l}2 \mathrm{hrs} . \\
\text { after }\end{array}$ & $\begin{array}{l}4 \mathrm{hrs} . \\
\text { after }\end{array}$ & $\begin{array}{l}6 \text { hrs. } \\
\text { after }\end{array}$ \\
\hline 6 & $\begin{array}{c}m l . \\
1000\end{array}$ & 255 & $\begin{array}{l}\text { Free } \\
\text { In peptides }\end{array}$ & $\begin{array}{l}4.80 \\
0.42\end{array}$ & $\begin{array}{l}6.02 \\
2.90\end{array}$ & $\begin{array}{l}6.49 \\
3.77\end{array}$ & $\begin{array}{r}\text { m. per } \\
4.26 \\
1.97\end{array}$ & $\begin{array}{l}3.94 \\
1.40\end{array}$ & $\begin{array}{l}4.18 \\
0.83\end{array}$ & \\
\hline 10 & 875 & 165 & $\begin{array}{l}\text { Free } \\
\text { In peptides }\end{array}$ & $\begin{array}{l}4.89 \\
0.16\end{array}$ & & $\begin{array}{l}6.45 \\
5.22\end{array}$ & $\begin{array}{l}3.71 \\
3.37\end{array}$ & $\begin{array}{l}4.49 \\
2.08\end{array}$ & & $\begin{array}{l}4.28 \\
1.04\end{array}$ \\
\hline 14 & 485 & 100 & $\begin{array}{l}\text { Free } \\
\text { In peptides }\end{array}$ & $\begin{array}{l}4.64 \\
0.46\end{array}$ & $\begin{array}{l}6.15 \\
2.34\end{array}$ & $\begin{array}{l}5.93 \\
3.53\end{array}$ & $\begin{array}{l}4.36 \\
1.17\end{array}$ & & $\begin{array}{l}4.68 \\
0.67\end{array}$ & \\
\hline 24 & 1000 & 120 & $\begin{array}{l}\text { Free } \\
\text { In peptides }\end{array}$ & $\begin{array}{l}5.15 \\
0.50\end{array}$ & & $\begin{array}{l}8.47 \\
6.29\end{array}$ & $\begin{array}{r}6.00 \\
2.49\end{array}$ & & $\begin{array}{l}4.35 \\
0.75\end{array}$ & \\
\hline
\end{tabular}

TABLE II

Urinary loss of amino acids and peptides of a fibrin hydrolysate infused intravenously

\begin{tabular}{|c|c|c|c|c|c|c|}
\hline \multirow{2}{*}{$\begin{array}{l}\text { Expt. } \\
\text { No.* }\end{array}$} & \multirow{2}{*}{$\begin{array}{l}\text { Volume } \\
\text { infused }\end{array}$} & \multirow{2}{*}{$\alpha$-amino $N$} & \multirow{2}{*}{$\begin{array}{l}\text { Pretest period. } \\
\text { fasting } \\
12 \text { hours }\end{array}$} & \multirow{2}{*}{$\begin{array}{l}\text { Infusion period } \\
\text { and succeeding } \\
6 \text { hours }\end{array}$} & \multicolumn{2}{|c|}{ Extra loss } \\
\hline & & & & & Net & $\begin{array}{c}\text { Fraction of } \\
\text { category infused }\end{array}$ \\
\hline 6 & $\begin{array}{c}m l . \\
1000\end{array}$ & $\begin{array}{l}\text { Total } \\
\text { Free } \\
\text { In peptides }\end{array}$ & $\begin{array}{c}\text { mgm. per hr. } \\
11.00 \\
3.44 \\
7.56\end{array}$ & $\begin{array}{c}\text { mgm. per hr. } \\
130 \\
22.2 \\
108\end{array}$ & $\begin{array}{r}m g m . \\
1070 \\
164 \\
900\end{array}$ & $\begin{array}{c}\text { per cent } \\
20 \\
8.3 \\
26\end{array}$ \\
\hline 10 & 875 & $\begin{array}{l}\text { Total } \\
\text { Free } \\
\text { In peptides } \\
\text { Total extractablet }\end{array}$ & $\begin{array}{r}14.34 \\
5.12 \\
9.22 \\
5.26\end{array}$ & $\begin{array}{r}124.2 \\
21.6 \\
102.6 \\
13.3\end{array}$ & $\begin{array}{r}970 \\
146 \\
825 \\
71\end{array}$ & $\begin{array}{l}21 \\
8.5 \\
28 \\
81\end{array}$ \\
\hline 14 & 485 & $\begin{array}{l}\text { Total } \\
\text { Free } \\
\text { In peptides }\end{array}$ & $\begin{array}{r}13.01 \\
4.30 \\
8.71\end{array}$ & $\begin{array}{r}105.3 \\
20.2 \\
85.1\end{array}$ & $\begin{array}{r}542 \\
93 \\
448\end{array}$ & $\begin{array}{l}21 \\
9.7 \\
27\end{array}$ \\
\hline 24 & 1000 & $\begin{array}{l}\text { Total } \\
\text { Free } \\
\text { In peptides } \\
\text { Total extractablet }\end{array}$ & $\begin{array}{l}2.66 \\
1.97 \\
0.69 \\
0.25\end{array}$ & $\begin{array}{c}149 \\
41.8 \\
107 \\
9.7\end{array}$ & $\begin{array}{r}1266 \\
345 \\
921 \\
82\end{array}$ & $\begin{array}{l}23 \\
17 \\
27 \\
82\end{array}$ \\
\hline $30 * *$ & 730 & $\begin{array}{l}\text { Total } \\
\text { Free } \\
\text { In peptides }\end{array}$ & $\begin{array}{l}39.60 \\
25.90 \\
13.70\end{array}$ & $\begin{array}{r}116 \\
36 \\
80\end{array}$ & $\begin{array}{r}684 \\
91 \\
594\end{array}$ & $\begin{array}{c}17.3 \\
6.2 \\
24\end{array}$ \\
\hline
\end{tabular}

* See the notes to Table $I$.

t Extracter from acidified urine by 5 portions of ethyl acetate, 1.5 volumes each extraction.

** Hepatic cirrhosis; infusion in 165 minutes. See text.

mainly hippuric acid $(3,4)$, rather than peptides. The ethyl acetate-extractable conjugates of urine were increased by the infusion of the fibrin hydrolysate (Table II); the increases, however, represented only 9 per cent of the extra conjugated $\alpha$ amino nitrogen excreted. About 1.8 per cent of the total $\alpha$-amino nitrogen could be extracted from the hydrolysate itself under the same conditions.
The additional extractable conjugates of the experimental urines may have arisen by preferential excretion of extractable peptides or by acylation of non-extractable peptides or amino acids.

To explore the possibility that impaired liver function might seriously handicap peptide utilization, $730 \mathrm{ml}$. of the fibrin hydrolysate solution were infused in 165 minutes into a 56-year-old male with 


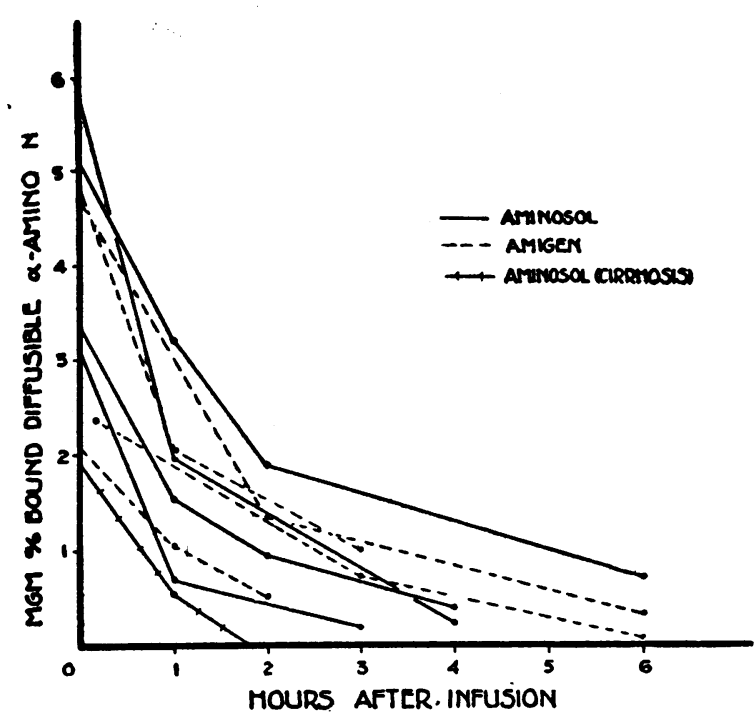

Fig. 1. Removal from Plasma of the Peptides InTRODUCED BY THE INFUSION OF INCOMPLETE HydROLYSATES of Fibrin and Casein

The pre-experimental level of conjugated amino acid nitrogen has been deducted in each case. The term "Aminosol" refers to the experimental fibrin hydrolysate.

cirrhosis and ascites. ${ }^{2}$ The patient yielded the following laboratory findings: bromsulfalein retention, 48 per cent after 1 hour (dose, $5 \mathrm{mgm}$. per Kilo) ; serum alkaline phosphatase, $9.6 \mathrm{King}$ units; icterus index, 14 ; cephalin flocculation test, ++++ ; normal urea clearance. The pretest excretion of amino acid nitrogen (free and conjugated) was about a gram per day (Table II). This patient showed the smallest loss observed of the infused free amino acids and peptides (Table II). The rise in the plasma concentration of peptides at the end of the infusion was small, and these peptides were removed relatively quickly (Figure 1).

\section{EXPERIMENTAL}

The fibrin hydrolysate solution used was derived from a single lot and was supplied through the kindness of Dr. Douglas V. Frost of Abbott Laboratories. According to Dr. Frost the hydrolysis had been performed by acid at $100^{\circ}$ for 6 hours, and the solution contained 7.2 grams of nitrogen per liter. Our analyses for this lot showed 1.98 grams of free $\alpha$-amino nitrogen and 5.42 grams of total $\alpha$-amino nitrogen (by acid hydrolysis) per liter, showing 64 per cent of the $\alpha$-amino nitrogen to be bound. These

2 This infusion was studied through the courtesy of Dr. Francis F. Harrison. analyses correspond quite well with those obtained by Frost for other lots.

Experimental details and analytical procedures were as described elsewhere (1).

\section{DISCUSSION}

The average sizes of the peptides of the 2 hydrolysates are similar, containing as an average, for Amigen (5), 3.4 and for the fibrin hydrolysate, 4.0 amino acid molecules per peptide molecules. $^{8}$ The difference in the availability of the peptides may be a result of differences in the 2 proteins, casein and fibrin, as to what amino acids are adjoining or may be a result of the different modes of hydrolysis, namely, by pancreatic enzymes and by acid. The first view that the difference is inherent in the proteins is supported by 2 conclusions of Frost, et al. (2), upon comparing the fibrin hydrolysate with a casein hydrolysate prepared in the same way by acid:

1. The superior biological value of the fibrin hydrolysate was not adequately explained by a higher content of essential amino acids.

2. Methionine in the state in which it is present in the casein hydrolysate appeared to be poorly utilized.

These observations suggest that the peptides of the hydrolysate of casein by acid, like those of the enzymatic hydrolysate, were not well utilized.

\section{SUM MARY}

Although our conclusion has been confirmed that peptides are less readily utilized than free amino acids when partial hydrolysates of protein are administered intravenously, the peptides of a fibrin hydrolysate were lost into the urine to a distinctly smaller extent than were the peptides of an enzymatic casein hydrolysate. The total amino acid losses of the 2 hydrolysates were similar. One may conclude that any partial hydrolysate of protein for intravenous nutrition offers the possibility of quantitatively or qualitatively serious losses of bound amino acids.

\footnotetext{
${ }^{8}$ The hydrolysis of fibrin has recently been extended to a degree of completeness similar to that of the casein hydrolysate. The term "Aminosol" is now applied to this preparation. The increased hydrolysis has intensified the difference in peptide utilization, urinary losses of peptides with the new preparation being, in 3 cases, only 16, 18 , and 10 per cent-the total losses of amino acids, 8.4, 11, and 5.5 per cent.
} 
Thanks are due to Dr. Scott P. Christensen for assistance.

\section{BIBLIOGRAPHY}

1. Christensen, H. N., Lynch, E. L., and Powers, J. H., The conjugated, non-protein, amino acids of plasma. III. Peptidemia and hyperpeptiduria as a result of the intravenous administration of partially hydrolyzed casein (Amigen). J. Biol. Chem., 1946, 166, 649.

2. Frost, D. V., Heinsen, J., and Olsen, R. T., Partial acid hydrolysates of proteins. IV. Intravenous use of high levels of fibrin and casein hydrolysates in hypoproteinemic dogs. Arch. Biochem., 1946, 10, 215.

3. Henriques, V., and Sørensen, S. P. L., ther die quantitative Bestimmung der Aminosäuren, Polypeptide und der Hippursäure im Harne durch Formoltitration. Z. physiol. Chem., 1909, 63, 27.

4. Christensen, H. N., Cooper, P. F., Jr., Johnson, R. D., and Lynch, E. L. Glycine and alanine of body fluids; experimental modification. J. Biol. Chem., 1947, 168, 191.

5. Cox, W. M., Jr., and Mueller, A. J., The relative efficiency of different forms of intravenously administered nitrogen on nitrogen balance and amino acid excretion. J. Nutrition, 1946, 31, 581. 